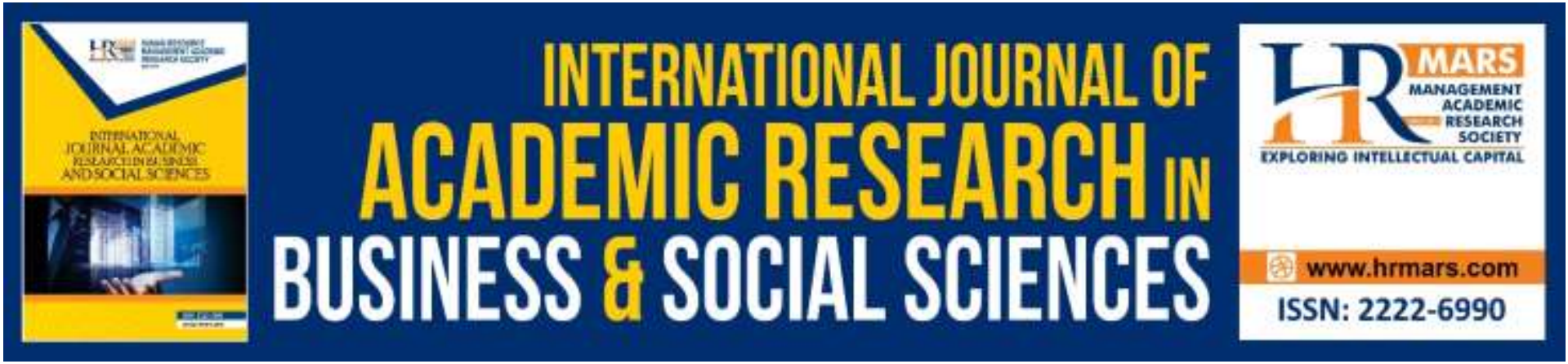

\title{
Determinants of Job Stress in Affecting Employees' Life: A Study on the Malaysian Manufacturing Sector
}

Nurul Ezaili Alias, Nurul Suhaida Sehat, Rozana Othman, Najihah Hanisah Marmaya, Wei-Loon Koe

To Link this Article: http://dx.doi.org/10.6007/IJARBSS/v9-i7/6224

DOI: 10.6007/IJARBSS/v9-i7/6224

Received: 09 May 2019, Revised: 19 June 2019, Accepted: 05 July 2019

Published Online: 31 July 2019

In-Text Citation: (Alias, Sehat, Othman, Marmaya, \& Koe, 2019)

To Cite this Article: Alias, N. E., Sehat, N. S., Othman, R., Marmaya, N. H., \& Koe, W.-L. (2019). Determinants of Job Stress in Affecting Employees' Life: A Study on the Malaysian Manufacturing Sector. International Journal of Academic Research in Business and Social Sciences, 9(7), 614-627.

Copyright: @ 2019 The Author(s)

Published by Human Resource Management Academic Research Society (www.hrmars.com)

This article is published under the Creative Commons Attribution (CC BY 4.0) license. Anyone may reproduce, distribute, translate and create derivative works of this article (for both commercial and non-commercial purposes), subject to full attribution to the original publication and authors. The full terms of this license may be seen at: $\underline{\text { http://creativecommons.org/licences/by/4.0/legalcode }}$

Vol. 9, No. 7, 2019, Pg. 614 - 627

Full Terms \& Conditions of access and use can be found at http://hrmars.com/index.php/pages/detail/publication-ethics 


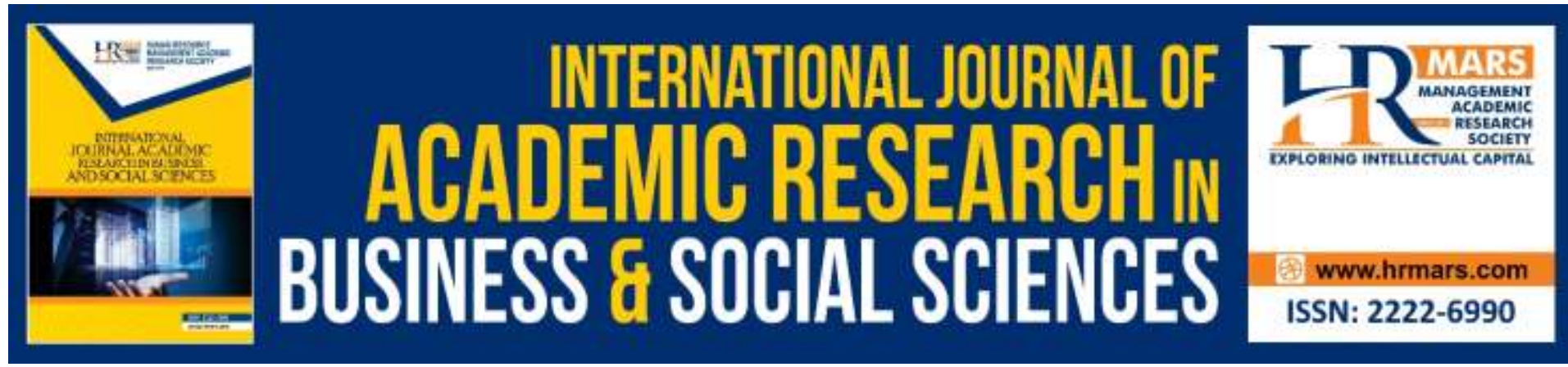

\title{
Determinants of Job Stress in Affecting Employees' Life: A Study on the Malaysian Manufacturing Sector
}

\author{
Nurul Ezaili Alias, Nurul Suhaida Sehat, Rozana Othman, \\ Najihah Hanisah Marmaya, Wei-Loon Koe
}

Faculty of Business \& Management, Universiti Teknologi MARA, Cawangan Melaka

\begin{abstract}
Stress is one of the common challenges the employees may face or experience when they work anywhere in the world. The issue regarding work-related stress is one of the serious problems that are faced by workers in Malaysia. Besides, the demands of the contemporary work environment stress are common at the workplace. However, the physical and mental wellbeing of the employees can be jeopardized if the job stress is still uncontrollable. There are several factors of job stress, such as work overload, role conflict, role ambiguity, and workfamily conflict. The purpose of this study is to examine the relationship between the antecedents of job stress and job stress. A total of 113 manufacturing employees were surveyed through a self-administered questionnaire. The analysis revealed only three (3) predictors of job stress, namely work overload, role conflict, and role ambiguity were positive and significantly influenced job stress. Only the predictor of work-family conflict has no significant relationship with job stress. As role conflict is the most significant factor to job stress, it further proposed that it is essential for organizations to explain clearly to the employees their job role, job responsibilities, organization policies, and guidelines, organization expectations to help them to set a clear objective to contribute to the organizational success. Further, the manager needs to pay more attention to care about the amount of work given to reduce work-related stress and they must provide clear instructions to their subordinates about the tasks, duties, and responsibilities granted to the employees. Keywords: Job Stress, Work Overload, Role Conflict, Role Ambiguity, Work-Family Conflict, Manufacturing

\section{Introduction}

Over the last few decades, almost three billion workers in every organization around the world face serious problems called "stress." Growing in the competition are lead to an increase in the levels of stress among employees in the workplace. Also, the problem known as job stress has exceeded acceptable limits and will negatively impact on employees. Hence, to produce quality work comfortably, companies need to deal with the most important problem, which is job stress (Khuong \& Yen, 2016).
\end{abstract}


Development of a country depends on the role that is played by an organization. Nowadays, employers and employees are working for the sake of money and profit. If the workers are not satisfied with their work, they may feel stress. Then, the employee will not complete the work effectively and efficiently. Thus, this also will negatively impact on the goodwill of the organization (Riaz et al., 2016). Therefore, it shows that the success of an organization depends on its valuable asset called employees.

Malaysia is one of the developing countries in the world with their financial plant and heavy economic schedules to bring the nation to become a fully developed country by the year 2020. To achieve the country's aims and ambitions, the force behind the schedules and plans which employees are doing their best. However, the issue regarding work-related stress is one of the serious problems that are faced by workers in Malaysia (Mallow, 2016).

In recent statement stated in the Malaysia New Straits Time Online, April 2016, the demands of the contemporary work environment stress are common at the workplace. However, the physical and mental wellbeing of the employees can be jeopardized if the job stress is still uncontrollable. Also stated that one of the most challenging issues is workrelated stress. If work-related stress problems are not well managed, it can be very costly to the workers as well as to the organization.

Job stress can arise at a different level in the workplaces. When the employee faced with stress, it can lead the employees to depression and conflict. Thus, stress was becoming a serious issue that is not the only impact on the individual of employees but also gives a negative impact on the organization. To solve and prevent the problem of job stress, a few organizations are now very concerned about the ways of coping up with job stress (Jalagat, 2017).

Also, stress can affect health, work performance, social life, and also the family member relationship. The response to stress is a complex emotion that produces physiological changes to make us into choosing between fight or accept, which means to defend ourselves or to escape from it. Therefore, individual and organization need to understand the stressors, and its consequences are very important. Work-related stress has become the main issue for businesses and has reached an alarming level. Furthermore, it is important for every organization to develop stress prevention as well as the way to reduce, prevent, minimize, and also to overcome the problem (Deshpande, 2012; Jalagat, 2017).

A valuable asset that an organization has called as employees, and they are not machines. Hence, free stress working environment can make employees more productive in their organization. But, if the organizations are not concerned with the issue, it can lead to the absenteeism, increase turnover rate, the ineffectiveness of work from employee and usually legal financial damage. Further, continuously ignoring the issue, employees will become unmotivated and unproductive, but it's also contributed to the physical and mental diseases (Rizwan, Raza, Mateen, Tehseen, \& Shahaid, 2014).

One of the key factors to a successful workplace is depending on how an organization is coping with the work-related stress problem. Stress and distress, there are two categories of stress. If the employees who are capable of fulfilling job demands, then the employees are experiencing with the stress while when workers who are not capable of satisfying job demands, it means the employees are facing with the distress. Stress may lead the employees to improve the quality of their work-life while distress may lead the employees to decrease the quality of their work life. Besides, stress also may be negative or positive. Positive stress is when it provides the opportunity to get something valuable to someone, and it will act as a 
motivation for better performance while negative stress is when someone faces the physical, emotional, social, and organizational troubles (Sheraz, Wajid, Sajid, \& Rizwan, 2014).

The NIOSH (National Institute of Occupational Safety and Health) Chairman says good mental health among each employee is very important because a healthy mind can achieve a safe, healthy and productive workforce, as reported in the Malaysia New Star Online. Experts have warned that by 2020, this issue of mental illness has become a serious issue after heart diseases. Besides, he also stressed that employees in Malaysia are not only suffering from work-related stress, as well as workplace-related depression (Thye, 2017). Further, the Executive Director of Malaysian Employers Federation's (MEF) added that the number of workplace-related depression in this country is increasing, and the factors that contribute to these situations are not only loss of employment, financial issues, lack of parental knowledge, substance abuse and anger management, but as well as family problem and work stress.

In 2013, Regus's online survey conducted and a majority of Malaysian people suffers from work-related stress. The result showed $70 \%$ of workers in Malaysia suffered from workrelated stress illnesses. It is also shown that the number of respondents who are sleepless due to work-related worries is over $42 \%$, and the worries are regarding salary, work burden, and job security. In fact, $48 \%$ of Malaysian respondents also felt that their level of work stress has increased. It is important for us to know that when the pressure in the work environment increases, it can adversely affect the body and the mind of the employees. At the same time, stress also can affect their personal life, consequently resulting in low job satisfaction and low productivity (Mallow, 2016).

In a recent survey by the "Malaysia's Healthiest Workplace by AIA Vitality Survey 2017", conducted to 47 organizations that included 5,369 employees. It is reported that there are more than half of employees are suffering from mental health issues, $12 \%$ of employees result in high levels of depression and most importantly and related to the study, $53 \%$ of Malaysian employees experienced at least one dimension of work-related stress. "Malaysian workers are most stressed," says the survey. In addition, the workforce in Malaysia is generally unhealthy, where $64 \%$ physically inactive. Besides, employees in Malaysia lose 67 days a year to absenteeism or presenteeism due to poor fitness and health. Also, it costs to RM 2.7 million per organization was estimated regarding the average yearly cost of healthrelated absenteeism and presenteeism. According to the survey, employees in Malaysia carried more health risks compared to their three peers countries, which are Hong Kong, Singapore, and Australia. One of the factors that drive to this condition is job stress observed (Mei Fong, 2017).

Job stress usually affects people in many sectors, and it is becoming pervasive nowadays. If the issue of high-stress level in the workplace cannot be controlled and managed by the organizations, it will consequently give negative outcomes, for instance, absenteeism rate and employee turnover rate (Alias, Rohmanan, Ismail, Koe, \& Othman, 2018). The Malaysian manufacturing industry also cannot be exempted from the struggle of reducing the number of employee turnover, and it is a stressful event to the management (Othman, Alias, Ariadi, Abdullah, Koe, Ismail, \& Ridzuan, 2017). Further, this critical phenomenon had received greater concern by the Malaysian government as in 11th Malaysian Plan (20162020), due to services and manufacturing industries continue to be the major contributors to Malaysia's economic growth (Economic Planning Unit, 2015).

In conclusion, Malaysia is not exempt from suffering the work-related stress problems affecting all workers in the workplace. Job stress does not only affect themselves but also to 
the organization and country. Thus, this study examined the influence of work overload, role ambiguity, role conflict, and work-family on job stress, specifically in manufacturing firms in Malaysia.

\section{Literature Review}

The word "stress" is a very common term which is known as pressure, either psychological or physiological, that an individual feel in their life. In a simple definition, stress can occur when an individual need to overcome their demands and capabilities. As mentioned earlier, stress also may be negative or positive. There are several factors of job stress, which are work overload, role conflict, role ambiguity, and work-family conflict and those factors were hypothesized to have a significant relationship with job performance (Moaz et al., 2016). While, in another study by Khuong \& Yen, (2016), investigated the effects of job stress on employee job performance, there are numerous factors that can have effects on job stress and job performance and the study found that factors of role ambiguity and role conflict, work overload, working relationship, working environment, and career development have relationship with job stress.

According to Sathasivam, Malek, \& Abdullah, (2015), in today's organization, workrelated stress always arises, and the cost of this phenomenon is across all levels of society. The study researched the relationship of organizational stressors like conflict, work overload, unfavourable work condition, and the moderating role of personality traits among managers and the study found that the key stressor of organizational is conflict, work overload, and unfavourable work condition.

On the other hand, Naghieh, Montgomery, Bonell, Thompson, \& Aber (2015) stated that work relates to stress can be due to work overload. Stress also can occur in the workplace when individuals feel that they are treated unfairly by others. Besides, lack of information, lack of feedback on the employee's performance, lack of resources to do carry out the task also can result in job stress. There is also a potential source of stress related to the nature of the work itself, such as the physical working conditions, type of tasks given, and the amount of satisfaction derived from the work. Besides, another factor that contributed to the workrelated stress is when the management has set unrealistic Key Performance Indicators (KPI) for the employees. Level of stress among employees will increase when they received unrealistic KPI.

Therefore, amongst all antecedents of job stress, there are four (4) dominant factors that researched in this study and this study has examined the effect of work overload, role conflict, role ambiguity, and work-family conflict on job stress.

\section{Work Overload and Job Stress}

Work overload is when an employee feels that they have a large amount of work to do than what they able to complete within a time given. There are very common when the employee feels that they have too much work to do in a day, but there is too little time to complete the given job. It is called the perception of employees, and this problem often referred to as work overload. Work overload comes from a variety of factors such as lack of appropriate break periods, unrealistic deadlines, and expectations are increasing. Throughout a wide variety of occupation, it is a common cause of work-related stress that exists (Moaz et al., 2016). The main problem faced by almost every sector of the organization is work overload. It has become a major focus when employees need to increase their working hours, time to 
complete the task, and pressure from supervisors to achieve competitiveness, and goals of the company. Work overload can occur when the employees feel that the level of demand exceeds the capabilities that require them to complete the task (Abbasi, 2015).

Rizwan et al. (2014) study the causes of job stress among 150 bank employees. The result of the study shows that there is a significant positive relationship between work overload and job stress. On the other hand, according to lqbal (2017), from a total of 134 questionnaires were distributed, only 122 respondents returned the valid questionnaire. The study found that there is a negative and significant relationship between work overload and job stress. While Khuong \& Yen's (2016) study revealed that there is no significant relationship between work overload and job stress.

In addition, Bakker (2017), from the regression analysis, confirmed that work overload has positive and significantly related to job stress, and this research conducted on 461 respondents. Further, another similar finding has also found in Vanishree's (2014) study, and the study limits the scope to 200 employee's tenure equal to or more than three years in SMEs. Therefore, this study hypothesizes there is a positive and significant relationship between work overload and job stress; Hypothesis 1 (H1).

\section{Role Conflict and Job Stress}

Role conflict defined as a situation where a person is expected to play two incompatible roles, or it occurs when someone needs to act two different opposing roles (Moaz, Jamil, Ahmad, \& Ghouse, 2016). According to Khuong \& Yen (2016), one of the causes of job stress is role conflict. Role conflict can also impact employee's productivity, tension, dissatisfaction, and psychological withdrawal from the workgroup among employees. Devi \& Rani (2016) also stated that one of the most influencing factors of job stress is role conflict and the researchers stressed that it occurs when a person experiences with at least two conflicting job factor pressures. In Rizwan et al. (2014) and Yongkang, Weixi, Yalin, Yipeng, \& Liu's (2014) study, these studies researched on the relationship between role conflict and job stress on 150 bank employees and 220 employees respectively, both of the studies found that there is a positive and significant relationship between role conflict and job stress.

Further, in a bigger population of 530 employees of Iran's central insurance, a stratified random sampling technique is performed, and 118 employees selected as respondents by Soltani, Hajatpour, Khorram, \& Nejati (2013), the study also found that there is also a positive and significant relationship between role conflict and job stress. Furthermore, inadequate resources, a mismatch between abilities and requirements, incompatible requests from two or more people, compulsion to do things differently are all causes of job stress, and the same finding also found in Vanishree's (2014) study.

However, in another study by Khuong \& Yen (2016) intended to investigate the relationship between role conflict and job stress, and the result shows that there is no significant relationship between those variables. Therefore, this study hypothesizes that there is a positive and significant relationship between role conflict and job stress; Hypothesis $2(\mathrm{H} 2)$.

\section{Role Ambiguity and Job Stress}

Another factor that contributed to the job stress is role ambiguity. It occurs when people are unclear or uncertain about their expectations within a certain role, typically their role in the job or workplace. It also can be defined as when an individual received a lack of information required in carrying out a given assignment, such as limited authority and responsibility, lack 
of information, policies and organizational rules, and performance appraisal methods (Ammar, 2006).

According to Soltani et al. (2013), Vanishree (2014) and Iqbal (2017), role ambiguity is one of the influence factors that affect job stress. The purpose of both research paper is to investigate the effect of role ambiguity on employees' job stress, and the result from this research found there is a positive and significant relationship between variables. Iqbal (2017) further stated that more complex and rapid changes of organization exist in the management will increase the possibility of job stress level to be higher.

On the other hand, Rizwan et al. (2014) and Khuong \& Yen's (2016) study investigating the causes of job stress. The goal of this research is to uncover the roots and outcomes of job stress on the employees' performance. The data collected resulted that there is no significant relationship between role ambiguity and job stress. Therefore, this study hypothesized that there is a positive and significant relationship between role ambiguity and job stress; Hypothesis $3(\mathrm{H} 3)$.

\section{Work-Family Conflict and Job Stress}

Work-family conflict can be defined as the clash between the role of work and the role of the family, which is usually different (Greenhaus \& Beutell, 1985). Further, according to Darcy \& McCarthy (2012), a work-family balance has been defined as the degree in which an individual can balance their emotional and behavioral demands of both paid work and family responsibilities." Work-family conflicts occur when an employee finds themselves struggling to compete for demands of work and family. The excessive pressure may adversely affect their ability to cope with those demands, and this can lead individuals to feel dissatisfaction, absenteeism, poor personal relations, and decreased their work performance (Anafarta, 2012).

Work-family conflict also can occur when the domains of work and home spill over into one another, causing conflict. Hence, work-family conflict is one of the causes of job stress (Khuong \& Yen, 2016). In modern life, there are many problems within different dimensions, and work-family conflict is one of the factors that have considerable effects. Work-family conflict can have effects on employees' organizational commitment, job stress, and job performance besides other common factors (Nart \& Batur, 2014). The study among teachers shows there is a positive correlation between work-family conflict and job stress. Means that work-family conflict perception increases job stress.

Work-family conflict is bidirectional, which means work issues can cause conflict at home and vice versa. Lambert, Qureshi, Frank, Keena, \& Hogan (2017) and Rizwan et al. (2014) investigated the relationship between work-family conflict and job stress among Indian police officers and bank employees, respectively. The result of the study shown that there is a positive and significant relationship between work-family conflict and job stress. In Jamadin, Mohamad, Syarkawi, \& Noordin's (2015) study, investigated on GLCs (governmentlinked companies) in East Malaysia, found that there is a positive and significant correlation between work-family conflict and job stress. Therefore, this study hypothesized that there is a positive and significant relationship between work-family conflict and job stress; Hypothesis 4 (H4). 


\section{Research Methodology}

The purpose of this research is to investigate the relationship between work overload, role conflict, role ambiguity, and work-family conflict and job stress among employees in Malaysia's manufacturing firms. The studied firms are the manufacturing companies in Malaysia and located in the Southern region of Malaysia. The firms were established in 1990, and are manufacturing the component parts, machinery, and equipment. The questionnaires consist of 5 sections. Section A includes the demographic detail of respondents. Section B is related to the dependent variable, and section $C, D, E$, and $F$ are related to the independent variables of the study. A total of 113 questionnaires distributed to all employees and 110 valid questionnaires returned.

The measurement items in this study were adopted from previous and established instruments. Specifically, it adopted 13 items from Al-ghamdi (2017) to measure perceived job stress. It is important to note that this study regarded job stress as a construct that contained four antecedents (work overload, role conflict, role ambiguity, and work-family conflict); thus, it adopted 46 items from Al-ghamdi (2017), House \& Schuler (1983), and Donovan, Foti, \& Hauenstein (2004) to measure the 4 predictors of job stress. The internal consistency reliability analysis of all measurement items was assessed through Cronbach alpha $(\alpha)$ and revealed that all the scales adopted in this study were accepted with alpha's value between $0.80<\alpha<0.90$. Multivariate statistical analysis using Statistical Package for the Social Science (SPSS) software was carried out to analyze the data collected. The findings in this study were reported through analyses of descriptive statistics, frequency, Pearson correlation, and multiple regressions analysis.

\section{Findings}

\section{Respondents' Background}

From 113 questionnaires were distributed, only 110 respondents responded valid questionnaires. Thus, this study represented from 110 employees of manufacturing firms. Majority of the respondents were male $(n=69 ; 62.7 \%)$. The highest of respondents were from Department of Marketing and Fabrication ( $n=15 ; 13.6 \%$ respectively), Department of Finance $(n=14 ; 12.7 \%)$, Department of Production ( $n=11 ; 10.0 \%)$, Department of Purchasing and Logistic ( $n=8 ; 7.3 \%$ respectively), Department of HR and R\&D ( $n=7 ; 6.4 \% \& n=5 ; 4.5 \%$ respectively), Department of QC and OSH ( $n=4 ; 3.6 \%)$, Department of IT, Corporate and Communication, and Welding $(n=3 ; 2.7 \%)$, and Department of Dipping, Machining, Plastic, Stamping, and Tooling ( $n=2 ; 1.8 \%)$.

Further, majority of the respondents hold a degree ( $n=59 ; 53.6 \%)$, followed by a diploma $(n=43 ; 39.1 \%)$ and the rest of the respondents with primary school's qualifications and certificates ( $n=7 ; 6.3 \% \& n=1 ; 0.9 \%$ respectively). In addition, the highest majority of the respondent's age were between $18-29$ year old $(n=51 ; 46.4 \%)$, followed by $30-39$ year old $(n=50 ; 45.5 \%)$, and $40-49$ year old $(n=9 ; 8.2 \%)$. Furthermore, half of the respondents' tenure was between $1-5$ years $(n=51 ; 46 \%)$, followed by $6-10$ years $(n=29 ; 26.4 \%),<1$ year $(n=24$; $21.8 \%$ ), and $11-15$ years ( $n=6 ; 5.5 \%$ ). Hence, from their background of academic qualification, age, and tenure, this frequency analysis can be concluded that most of the respondents are a degree holder, with a young age between 18-29 year old, and have working experience for at least $1-5$ years. 


\section{Mean, Correlations and Regressions Analyses}

The descriptive statistics analysis findings; mean and standard deviation, of the five variables studied in this paper, was reported in below Table 1. As for the elements of job stress, respondents rated role conflict the highest $(m=4.00 ; S D=0.61)$, followed by work-overload $(m=3.99 ; S D=0.60)$, work-family conflict $(m=3.56 ; S D=0.91)$ and role ambiguity $(m=2.76$; $\mathrm{SD}=0.86)$. Interestingly, the employees also perceived job stress $(m=3.82 ; S D=0.65)$. In average, all variables items were agreed by the respondents, excepted role ambiguity, where all respondents were neutral with all the variable items.

In order to determine the associations between variables, predictors of job stress (as independent variables) and job stress (dependent variable), Pearson correlation, coefficient $(r)$, was performed in Table 1. It reveals that all variables (work-overload, role conflict, role ambiguity, work-family conflict, and job stress) were significantly correlated between variables $(0.469 \leq r \leq 0.669 ; \mathrm{sig}<0.01)$. It also confirmed that there is no multicollinearity issue, as the greatest $r$-value was 0.669

Table 1 Mean, standard deviation and correlations

\begin{tabular}{llll}
\hline & $\mathrm{m}$ & $\mathrm{SD}$ & $\begin{array}{l}\text { Pearson } \\
\text { Correlation, } r \\
\text { Job Stress }\end{array}$ \\
\hline Job Stress & 3.82 & 0.65 & 1 \\
Work-Overload & 3.99 & 0.60 & $.607^{* *}$ \\
Role Conflict & 4.00 & 0.61 & $.669^{* *}$ \\
Role Ambiguity & 2.76 & 0.86 & $.482^{* *}$ \\
Work-Family Conflict & 3.56 & 0.91 & $.469^{* *}$ \\
\hline Sig. (2-tailed); N=110 & & & \\
\hline
\end{tabular}

The hypotheses of this study were investigated through multiple linear regressions as reported in Table 2. There are 4 hypotheses that have been tested. The table findings indicated that the model was statistically significant, as the F-value obtained was 36.608 (sig. $<0.01)$. The $R$-squared value attained was 0.582 and this explained that all independent variables of this study explicated the variance in job stress as much as $58.2 \%$. The results of multiple linear regressions revealed that all the independent variables; work-overload, role conflict, role ambiguity, and work-family conflict were found to have a positive relationship with the dependent variable; job stress. However, only 3 independent variables shown a positive and significant relationship with dependent variable, there are work-overload $(\beta=0.357$; sig. $<0.01)$, role conflict $(\beta=0.384$; sig. $<0.01)$ and role ambiguity $(\beta=0.191 ;$ sig. $<0.01)$, while 1 independent variable, which is work-family conflict $(\beta=-0.035$; sig.>0.05) had no significant relationship with job stress. From the multiple regression analysis, it confirmed that the most significant factor influencing job stress was role conflict with the highest beta value $(\beta=0.384 ;$ sig. $<0.01)$. Therefore, the results of the hypotheses proved that only $\mathrm{H} 1, \mathrm{H} 2$ and, $\mathrm{H} 3$ were supported, while $\mathrm{H} 4$ was not supported. 
Table 2 Multiple Regression Analysis

\begin{tabular}{llll}
\hline & $\begin{array}{l}\text { Standardized } \\
\text { Coefficients } \\
\text { (Beta) }\end{array}$ & t & Sig. \\
\hline Work-Overload & .357 & 4.899 & .000 \\
Role Conflict & .384 & 4.431 & .000 \\
Role Ambiguity & .191 & -2.619 & .010 \\
Work-Family Conflict & .035 & .446 & .657 \\
& & & \\
\hline F value = 36.608; Sig. =0.000 & & \\
\hline $\begin{array}{l}\text { R }=0.763 \\
\text { R Square = 0.582 }\end{array}$ & & \\
$\begin{array}{l}\text { Adjusted R square = 0.567 } \\
\text { Std. Error of the Estimate = 5.549 }\end{array}$ & \\
\hline $\begin{array}{l}\text { a. Predictors: (Constant), Work Overload, Role Conflict, Role Ambiguity, Work-Family } \\
\text { Conflict } \\
\text { b. Dependent Variable: Job Stress }\end{array}$ & \\
\hline
\end{tabular}

\section{Discussion}

This study was conducted to highlight the relationship between work overload, role conflict, role ambiguity, work-family conflict, and job stress. There are four hypotheses in this study to examine the significant relationship between independent and dependent variables. There were only three hypotheses accepted in this study. Hypothesis $1(\mathrm{H} 1)$ was there is a significant relationship between work-overload and job stress. Based on the findings of multiple linear regression analysis, it revealed that there is a positive and significant relationship between work-overload and job stress. The result explains that as the value of work-overload increase, hence the job stress will also increase. This finding of hypothesis $1(\mathrm{H} 1)$ was consistent in the findings of Rizwan et al. (2014), Bakker (2017) and Vanishree (2014). Hypothesis 2 (H2) there is a significant relationship between role conflict and job stress, and the findings confirmed that there is a positive and significant relationship between role conflict and job stress. This finding indicates that if the employees experience from role conflict, thus the job stress will also increase in the same direction. This finding was consistent with previous studies by Rizwan et al. (2014), Yongkang, Weixi, Yalin, Yipeng, \& Liu (2014), Soltani, Hajatpour, Khorram, \& Nejati (2013) and Vanishree (2014). Finally, hypothesis 3 (H3), there is a significant relationship between role ambiguity and job stress, and it was found that there is a positive and significant relationship between role ambiguity and job stress. This result explained that if the role ambiguity among employees increases, hence their job stress will also increase. Soltani et al. (2013), Vanishree (2014), and Iqbal (2017) also reported the same findings.

On the other hand, there is no significant relationship between work-family conflict and job stress as the result explained that there no significant relationship between workfamily conflict and job stress. Means that employees can balance work and family conflict. They have their sense of ownership on their own life and will leave the family issue at home and work issue at work. So, work-family conflict is not affected their stress level. However, this finding contrasts with previous studies by Lambert, Qureshi, Frank, Keena, \& Hogan (2017), Rizwan et al. (2014), and Jamadin, Mohamad, Syarkawi, \& Noordin (2015). 
Building upon the social exchange theory, this paper hypothesized the direct effect of work overload, role conflict, and role ambiguity on job stress. Delegation of more relevant responsibilities and challenging tasks by leaders will influence to greater satisfaction and loyalty among workers (Lee, 2008; Tierney and Farmers, 2002). These findings can be explained by the theory of social exchange (Blau 1964), employees who work in a free workrelated stress environment would continue to stay longer with the organization. The higher the preferred rewards, job expectations, and desires, the higher the commitment to the job and organization (Chew and Chan 2008).

\section{Recommendation}

From the findings of this research, there are few recommendations for future researcher and practitioner's improvement. There are remaining 42 percent can be explained by other predictors that are not measured in this study. As all predictors of job stress in this study contribute to 58 percent in explaining job stress. According to Khuong \& Yen (2016), other factors can affect job stress are career development, work relationship, and working environment. Besides that, the previous study also stated, performance pressure and relationship with others are the causes of job stress (Iqbal \& Waseem, 2012).

In order to reduce the level of job stress among employees, organizations shall consider these study findings to improve the level of organizational performance and productivity. If the organization remain with no actions, a devastating situation such as losing motivation among employees especially the talented ones to perform better for the organization. Consequently, in the long run, the organization will not only losing their talented employees, but they will suffer from a tremendous increase of recruitment and hiring cost and to select the right candidate to replace the vacant position. In addition, based on the findings, by effectively managing the issue of work overload, role conflict, and role ambiguity among employees in organizations will lower the level of job stress.

An organization should play an important role to ensure employees are free from work-related stress. As for that, companies are recommended to take actions to prevent, minimize, and to overcome the problem of stress. Firstly, the manager of the organization needs to pay more attention to care about the amount of work given to reduce work-related stress. When the level of employee work-related stress is low, it can increase employee performance as well as increase organizational productivity. Work overload may be a hard factor to reduce. When an employee receives a large amount of work with different ability of the employee, work overload may occur. But, organizations still have solutions to resolve this issue. The companies may encourage their employees to prepare tasks priority lists to get done all the things they have to do. Most of the employees who faced job stress caused by work overload feel they don't have enough hours to perform the job in a day. Thus, organizations can provide training on time management among employees. Hence, by doing this, organizations will help their employees from facing work overload and consequently, it will reduce the job stress level.

Secondly, in reducing the issue of role conflict, it is essential for organizations to explain clearly to the employees their job role, job responsibilities, organization policies, and guidelines, organization expectations to help them to set a clear objective to contribute to the organization. Besides, clear communication and instruction must come from the superior, and this will make employees able to focus and differentiate the job given under different 
conditions. By providing adequate resources and materials to execute the job will also help to reduce the issue of role conflict among employees.

Lastly, the organization's leaders must provide clear instructions to their subordinates, so there will be no issue of role ambiguity among employees. Besides, conducting an effective job analysis for all positions that exist in the organization will help the employees to clearly understand their job descriptions, which are the tasks, duties, and responsibilities. Further, the explanations on the job descriptions must be clear and precise, for examples what and how to be done. In conclusion, employees will be free from work-related stress and can perform more effectively and efficiently as well as contributed to the organization's success.

\section{References}

Abbasi, T. F. (2015). Impact of Work Overload on Stress, Job Satisfaction, and Turnover Intentions with Moderating Role of Islamic Work Ethics. Management Studies and Economic Systems (MSES), 2(1), 27-37.

Alias, N. E., Rohmanan, N. H., Ismail, S., Koe, W. L., \& Othman, R. (2018). Factors Influencing Turnover Intention in a Malaysian Manufacturing Company. KnE Social Sciences, 771787.

Al-ghamdi, N. G. (2017). Role Overload and Job Stress among the Female University TeachersSaudi Context. European Online Journal of Natural and Social Sciences 2017, 6(2), 288295.

Ammar, T. (2006), The effect of internal variables on the level of job stress on the employees of Palestinian Universities at Gaza Strip. Master thesis, Islamic university, Gaza, 55.

Anafarta, N. (2011). The Relationship between Work-Family Conflict and Job Satisfaction: A Structural Equation Modeling (SEM) Approach. International Journal of Business and Management, 6(4), 168-177.

https://doi.org/10.5539/ijbm.v6n4p168

Bakker, K. (2017). Role Overload and Job Stress: The Role of Perceived Organizational Support, (June), 1-23.

Blau, P. M. (1964) Exchange and Power in Social Life. Wiley, New York, NY Chew J, Chan CCA (2008) Human resource practices, organizational commitment and intention to stay. Int J Manpower 29(6):503-522

Deshpande, R. C. (2012). A healthy way to handle work place stress through Yoga, Meditation and Soothing Humor Revati. International Journal Of Environmental Sciences Volume, 2(4), 2139-2144. https://doi.org/10.6088/ijes.00202030097

Devi, K. R., \& Rani, S. S. (2016). The Impact of Organizational Role Stress and Work Family Conflict: Diagnosis Sources of Difficulty at Work Place and Job Satisfaction among Women in IT Sector, Chennai, Tamil Nadu. Procedia - Social and Behavioral Sciences, 219, 214-220.

https://doi.org/10.1016/j.sbspro.2016.05.008

Economic Planning Unit. (2015). Strengthening Infrastructure to Support Economic Expansion. Rancangan Malaysia Kesebelas (Eleventh Malaysia Plan): 2016-2020. Retrieved from http://rmk11.epu.gov.my/book/eng/Elevent-Malaysia- Plan/RMKe-11 Book.pdfGreenhaus, J. H. \& Beutell, N. J. (1985). Sources of Conflict Between Work and Family Roles. Academy of Management Review, 10,76-88. 
House, R. J., Schuler, R. S., \& Levanoni, E. (1983). Role conflict and ambiguity scales: Reality or artifacts.

Iqbal, M. (2017). Impact of Job Stress on Job Satisfaction among Air Traffic Controllers of Civil Aviation Authority: An Empirical Study from Impact of Job Stress on Job Satisfaction among Air Traffic Controllers of Civil Aviation Authority: An Empirical Study from P. International Journal of Human Resource Studies, 2(May 2012), 53-70. https://doi.org/10.5296/ijhrs.v2i2.1854

Jalagat, R. (2017). Determinants of Job Stress and Its Relationship on Employee Job Performance Determinants of Job Stress and Its Relationship on Employee Job Performance. American Journal of Management Science and Engineering, 2(February), 1-10. https://doi.org/10.11648/j.ajmse.20170201.11

Jamadin, N., Mohamad, S., Syarkawi, Z., \& Noordin, F. (2015). Work - Family Conflict and Stress : Evidence from, 3(2), 2013-2016.

https://doi.org/10.7763/JOEBM.2015.V3.200

Khuong, M. N., \& Yen, V. H. (2016). Investigate the Effects of Job Stress on Employee Job Performance - A Case Study at Dong Xuyen Industrial. International Journal of Trade, Economics and Finance, 7(2). https://doi.org/10.18178/ijtef.2016.7.2.495

Lambert, E. G., Qureshi, H., Frank, J., Keena, L. D., \& Hogan, N. L. (2017). The relationship of work-family conflict with job stress among Indian police officers: a research note. Police Practice and Research, 18(1), 37-48.

https://doi.org/10.1080/15614263.2016.1210010

Lee, J. (2008) Effects of leadership and leader-member exchange on innovativeness. J Managerial Psychol 23(6):670-687

Lo, M. C., Thurasamy, R., \& Liew, W. T. (2014). Relationship between bases of power and job stresses: role of mentoring. SpringerPlus, 3(1), 432.

Fong, M. C. (2017). Malaysians work most hours but are least productive.

Moaz, N. G., Jamil, S. A., Ahmad, M., \& Ghouse, S. (2016). The impact of job stress on job performance : A case study on academic staff at dhofar university. International Journal of Economic Research, (May), 21-33.

Naghieh, A, Montgomery, P. Christopher, P. B., Thompson, M. and Lawrence, J. A. (2015) "Organisational interventions for improving wellbeing and reducing work-related stress in teachers." Cochrane Database of Systematic Reviews 4 (2015).

Nart, S., \& Batur, O. (2014). The relation between work-family conflict, job stress, organizational commitment and job performance : A study on turkish primary teachers, 2013(c), 72-81. https://doi.org/10.15527/ejre.201426250

Othman, R., Alias, N. E., Ariadi, N. S., Abdullah, A., Loon, K. W., Ismail, S., \& Ridzuan, A. R. (2017). Employee Retention in Emerging Economy: A Case of Gen $Y$ in Malaysian Manufacturing Company. Advanced Science Letters, 23(8), 7637-7640.

Riaz, M., Ahmad, N., Riaz, M., Murtaza, G., Khan, T., \& Firdous, H. (2016). Impact of Job Stress on Employee Job Satisfaction. International Review of Management and Business Research, 5(4), 1370-1382.

Rizwan, M., Raza, M. A., Mateen, M. A., Tehseen, F., Farooq, M. S., Javed, A., \& Javed, S. (2014). Investigating the causes of job stress: a study on banking sector of Bahawalpur, Pakistan. International Journal of Learning and Development, 4(2), 227. 
Sathasivam, K. V, Hj. A. Malek, D. M. D., \& Abdullah, P. D. A. (2015). Organizational Stressors and Job Stress Among Malaysian Managers : The Moderating Role of Personality Traits. International Journal of Social Work, 2(1), 1-21. https://doi.org/10.5296/ijsw.v2i1.7338

Sheraz, A., Wajid, M., Sajid, M., \& Rizwan, M. (2014). Antecedents of Job Stress and its impact on employee' s Job Satisfaction and Turnover Intentions. International Journal of Learning \& Development, 4(2), 204-226.

Soltani, I., Hajatpour, S., Khorram, J., \& Nejati, M. H. (2013). Investigating the effect of role conflict and role ambiguity on employees' job stress :Articulating the role of workfamily conflict. Management Science Letters, 3(7), 1927-1936. https://doi.org/10.5267/j.msl.2013.06.036

Thye, L. L. (2017). Investing in the mental health of workers.

Tierney, P., Farmer, S. M. (2002) Creative self-efficacy: its potential antecedents and relationship to creative performance. Acad Manage J 45:1137-1148Darcy, C., \& McCarthy, A. (2007). Work-family conflict. Journal of European Industrial Training, 31(7), 530-549.

https://doi.org/10.1108/03090590710820042Mallow, M. S. (2016).

Occupational Stress in Malaysia: Causes, Effects and Possible Solutions. Proceedings of SOCIOINT 2016 3rd International Conference on Education, Social Sciences and Humanities, (May), 82-88.

Vanishree, P. (2014). Impact of Role Ambiguity, Role Conflict and Role Overload on Job Stress in Small and Medium Scale Industries. Research Journal of Management Sciences Res. J. Management Sci, 3(1), 2319-1171.

Yongkang, Z., Weixi, Z., Yalin, H., Yipeng, X., \& Liu, T. (2014). The Relationship among Role Conflict, Role Ambiguity, Role Overload and Job Stress of Chinese Middle-Level Cadres, $3(1), 8-11$. 